\title{
A New Species of Elymus (Gramineae, Triticeae) from Eastern Australia
}

\author{
Surrey W. L. Jacobs \\ National Herbarium, Royal Botanic Gardens, Sydney, New South Wales 2000, Australia. \\ Author for correspondence: surrey.jacobs@rbgsyd.nsw.gov.au \\ Mary E. Barkworth \\ Intermountain Herbarium, Utah State University, Logan, Utah 84322-5305, U.S.A. \\ mary@biology.usu.edu
}

Abstract. A new species, Elymus fertilis Song Wang ex S. W. L. Jacobs \& Barkworth (Gramineae, Triticeae), is described from New South Wales and Queensland, Australia, with a New South Wales specimen being designated as its holotype. Elymus fertilis is similar to E. multiflorus (Banks \& Solander ex Hooker f.) Á. Löve \& Connor, but differs in having longer awns on the lowest lemma of the spikelet and in growing mostly on basic soils of volcanic origin, whereas E. multiflorus is more common on alluvial soils. A key is supplied for the Australian species of Elymus.

Key words: Elymus, Gramineae, IUCN Red List, Poaceae, Triticeae.

For a long time, only one species of what is now treated as Elymus L. was recognized in Australia, E. scaber (R. Brown) Á. Löve or, as it used to be called, Agropyron scabrum (R. Brown) P. Beauvois. This species was, however, known to be diverse (see, e.g., Rees, 1972) and was frequently referred to as a complex. With further study, additional taxa have been recognized. Thus, in 1989 Stanley and Ross recognized three taxa in southeastern Queensland: two species, E. scaber and E. multiflorus (Banks \& Solander ex Hooker f.) Á. Löve \& Connor, and two subspecies, E. scaber var. scaber and E. scaber var. plurinervis (Vickery) B. K. Simon. Subsequently, Wang and Henwood (1999) recognized one additional species, E. rectisetus (Nees in Lehmann) Á. Löve \& Connor, as growing in Australia. In her doctoral thesis, however, Wang (1999) recognized variety plurinervis at the species level and documented the existence of a hitherto unrecognized species for which she suggested the epithet "fertilis." Two of the specimens that she cited as belonging to this new species, Wang 95140 and 95158 , are cited as E. multiflorus in Wang and Henwood (1999).

Wheeler et al. (2002) and Wang and Jacobs (2002) followed the recommendations Wang (1999) made in her thesis, recognizing the two species as species A and B, with species A corresponding to Elymus scaber var. plurinervis and species B to the new taxon. More recently, Connor (2005) raised E. scaber var. plurinervis to specific rank, naming it $E$. plurinervis (Vickery) Connor, a decision that is well supported by morphological information (Murphy \& Jones, 1999). This paper concerns species B, the previously unrecognized taxon. We are convinced that it merits recognition as a distinct species on the basis of its morphological, ecological, and molecular distinction from other species in the E. scabrus complex (Wang, 1999; Wang \& Jacobs, 2002). To reduce the confusion resulting from its lack of a name and to provide a name for the next edition of Wheeler et al. (2002), we describe it here, using the epithet fertilis as suggested by Wang (1999), and provide a key to all the Australian species of Elymus to aid others in identifying them.

Elymus fertilis S. Wang ex S. W. L. Jacobs \& Barkworth, sp. nov. TYPE: Australia. [New South Wales]: urban area, Moree, $29^{\circ} 28^{\prime} \mathrm{S}, 149^{\circ} 51^{\prime} \mathrm{E}$, 13 Oct. 1988, N. Lloyd 759 (holotype, NSW 220373). Figure 1.

Elymo multifloro (Banks \& Solander ex Hooker f.) Á. Löve \& Connor similis sed ab eo spiculae lemmate infimo plerumque arista longiore et lemmatibus supernis arista longiore quam corpore munitis differt.

Caespitose perennial to ca. $55 \mathrm{~cm}$ tall; culms erect or drooping, 0.7-1.7 mm diam., glaucous, 3- to 6noded. Basal leaf sheaths glabrous or hairy, smooth; margins hyaline or membranous; auricles 0-1.9 mm, glabrous; ligules $0.4-0.5 \mathrm{~mm}$, membranous, truncate; collar glabrous or hairy; blade flat, to ca. $20 \mathrm{~cm} \times$ $1.8-4.7 \mathrm{~mm}$, adaxially glabrous or scabrous or hairy, abaxially glabrous or scabrous. Inflorescence axis $21-$ $70 \mathrm{~cm}$; peduncles glabrous or scabrous; internodes 20-38 mm, glabrous or scabrous. Spikelets 5 to 10 on the rachis, solitary at each node, the flat side against the axis, 26-39 mm, with 4 to 9 florets, the spikelets 


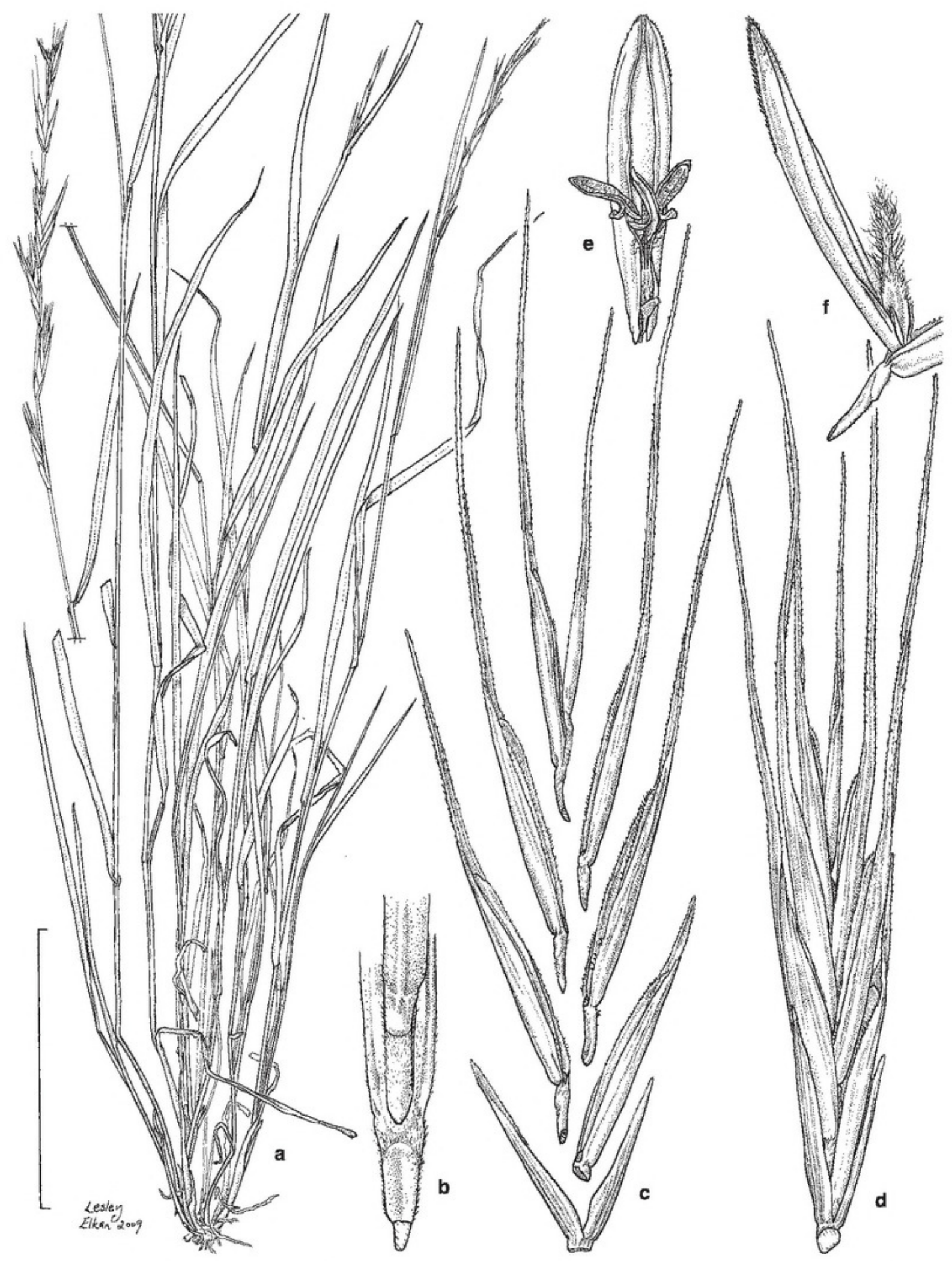

Figure 1. Elymus fertilis S. Wang ex S. W. L. Jacobs \& Barkworth. -A. Habit. -B. Callus as viewed from both sides. -C. Expanded view of spikelet showing shorter awns on lower lemmas. - D. Intact spikelet. - E. Palea, adaxial view, showing exserted stamens. - F. Floret in side view showing developing ovary. Drawn from the holotype Lloyd 759 (NSW220373). Scale bars: $\mathrm{A}=8 \mathrm{~cm} ; \mathrm{B}=0.4 \mathrm{~cm} ; \mathrm{C}, \mathrm{D}=1 \mathrm{~cm} ; \mathrm{E}, \mathrm{F}=0.6 \mathrm{~cm}$.

\pm equal to the internode length; glumes subequal; lower glume 4.8-6.1 $\times 0.8-1.2 \mathrm{~mm}$, glabrous or scabrous, 4- to 5-nerved, with a terminal awn 1$1.8 \mathrm{~mm}$ and membranous margin $0.3-0.6 \mathrm{~mm}$ wide; upper glume $5.6-7 \times 0.7-1.2 \mathrm{~mm}$, glabrous or scabrous, 4- to 6-nerved, with a terminal awn 1$1.5 \mathrm{~mm}$, and margins hyaline or membranous, 0.3$0.5 \mathrm{~mm}$ wide; rachilla segments $1.8-2.5 \mathrm{~mm}$, with 
short hairs; apical scar ovate, obovate to circular; callus $0.6-0.9 \mathrm{~mm}$, broadly triangular, dorsal surface flat or sunken, glabrous or glabrescent, tip not thickened, adaxial margin thickening, extending approximately to the midpoint; lemmas $8.5-10 \mathrm{~mm}$, dorsally glabrous or scabrous, not pruinose, 5-nerved; margins hyaline or membranous, $0.1-0.3 \mathrm{~mm}$ wide; apex acuminate, flat, entire or bifid, awned; awn on lowest lemma in each spikelet $2-7.7 \mathrm{~mm}$, those on other lemmas 4.4-15 mm, all awns remaining straight, when dry, scabrous, 3-nerved at base; palea 8-9.1 $\times$ 1-1.4 mm, 2-keeled; keels ciliolate with hairs 0.1$0.18 \mathrm{~mm}$; intercostal region scabrous or hairy; apex narrower to wider than lemma apex, truncate or obtuse, entire or retuse, side panels $0-0.27 \mathrm{~mm}$ shorter than the keel tips; lodicules 0.9-1.4 mm, margin lobed or entire; stamens 3 ; anthers 1.6$2.6 \mathrm{~mm}$, yellow or purple. Caryopsis narrowly elliptical or narrowly oblong, 5.2-6.7 $\times 1-1.3 \mathrm{~mm}$, longitudinally grooved or deeply furrowed.

Distribution and habitat. Elymus fertilis grows in southeastern Queensland and northern New South Wales. It usually grows on dark brown basaltic soils of volcanic origin, but is sometimes found on fertile alluvial soils. It grows in mixed populations with $E$. plurinervis in New South Wales, but not in Queensland. Elymus multiflorus usually grows on poorer soils in more coastal and riverine areas and is much more common farther south, extending through New South Wales, Victoria, and Tasmania.

IUCN Red List category. The new species is now almost completely confined to roadsides. Most of its natural distribution is on high-fertility soils that originally supported grasslands or grassy woodlands. It is estimated that well over $50 \%$ of such land has been lost to cultivation. While the cause of the loss is clear, it has not ceased, and most of the known populations are vulnerable. The data best fit the IUCN (2001) classification for Endangered (EN).

Etymology. The epithet fertilis was suggested by Wang (1999) because of the high seed set the species exhibits.

Reproductive biology. The high seed set, which is retained in cultivation (pers. obs.), strongly suggests that Elymus fertilis reproduces sexually (Connor, 1954; Murphy \& Jones, 1999). In this, it resembles both E. multiflorus and E. plurinervis but differs from E. scaber s. str. and E. rectisetus.

Cytology and genomic constitution. Elymus fertilis is probably a hexaploid with $2 n=42$ and a genomic constitution of StYW. (Genome designations follow the recommendations of the International Triticeae Con- sortium [1996+].) Chromosome counts and genomic analyses have been made for several accessions in the E. scaber complex (Torabinejad et al., 1987; Torabinejad \& Mueller, 1993), all of which were demonstrated to be hexaploids with a genomic constitution of StYW. According to the authors, the taxa studied include what are here called E. plurinervis, E. rectisetus, and E. scaber, although Connor (1994) noted that he would call one of the accessions identified as E. scaber, D2888, E. multiflorus. Torabinejad and Mueller (1993) cited the United States Department of Agriculture's Plant Introduction numbers for the accessions they studied, but no voucher specimens were cited. Consequently, we have not been able to verify any of the identifications. Nevertheless, it seems probable that $E$. fertilis resembles other members of the E. scaber complex in chromosome number and genomic constitution.

Molecular analysis. Random amplified polymorphic DNA analysis (Wang \& Jacobs, 2002) revealed 11 markers unique to Elymus fertilis, only slightly fewer than the 13 markers unique to $E$. plurinervis.

Paratypes. AUSTRALIA. New South Wales: North Western Plains, Moree, 7 May 1997, M. Murphy 4317 (NE). Queensland: betw. Laidley \& Forest Hill, 28 Nov. 1930, C. E. Hubbard 5311 (MEL, NSW); Ascot, Brisbane, 13 Aug. 1930, C. E. Hubbard 3654 (BRI, MEL, NSW); Cheribah turn-off, Warwick-Killarney rd., 25 Nov. 1985, J. G. Carmen 1025 \& B. K. Simon (NSW); Wallangara, 2 Jan. 1933, S. T. Blake 4414 (NSW).

\section{Key to Elymus in Australia}

N.B. Elymus repens (L.) Gould is sometimes placed in a separate genus, Elytrigia Desvaux.

1a. Plants with long, pale yellow vigorous rhizomes; lemmas acute but awnless (in Australia).... E. repens

1b. Plants caespitose; at least some lemmas usually awned . . . . . . . . . . . . . . 2

2a. Rachilla hairs usually $0.2-1 \mathrm{~mm}$ long; callus usually triangular to narrowly triangular, usually distinctly hairy . . . . . . . . . . . . 3

2b. Rachilla hairs $<0.2 \mathrm{~mm}$; callus broadly triangular, glabrous to glabrescent. . . . . . . . . 4

3a. Rachilla hairs usually not covering callus base; dorsal surface of callus flat to sunken; callus usually hairy on margins and surface sometimes glabrous to glabrescent; callus tip usually thickened .....E. scaber

3 b. Rachilla hairs covering callus base; dorsal surface of callus rounded; callus hairy only on the margins; callus tip not thickened ........... E. rectisetus

4a. Glumes $\geq 7.7 \mathrm{~mm}$; lemma awn usually curved when dry, 1-nerved at base; mature caryopsis $<55 \%$ palea length . . . . . . . E. plurinervis

4b. Glumes usually $<7 \mathrm{~mm}$; lemma awn straight when dry, 3-nerved at base; mature caryopsis $>60 \%$ palea length. . . . . . . . . . . . . 5

5a. Awn of lowest lemma $2-7.7 \mathrm{~mm}$; other lemma awns $4.4-15 \mathrm{~mm}$; ratio of awn to lemma length $0.7-1.3: 1 \ldots \ldots \ldots \ldots \ldots \ldots \ldots$. fertilis 
5b. Awn of lowest lemma 0-3 mm; other lemma awns $0-11 \mathrm{~mm}$ long; ratio of awn to lemma length $0.2-$ $0.8: 1 \ldots \ldots \ldots \ldots \ldots \ldots \ldots$. multiflorus

\section{Literature Cited}

Connor, H. E. 1954. Studies in New Zealand Agropyron. New Zealand J. Sci. Technol. Section B. 35(4): 315-343.

1994. Indigenous New Zealand Triticeae: Gramineae. New Zealand J. Bot. 32: 125-154.

2005. Flora of New Zealand-Gramineae Supplement II: Pooideae (Poeae, Triticeae). New Zealand J. Bot. 43: 493-507.

International Triticeae Consortium. 1996+. Genome designations in the Triticeae. <http://www.herbarium.usu.edu/ Triticeae/genmsymb.htm>, accessed December 2008.

IUCN. 2001. IUCN Red List Categories and Criteria, Version 3.1. Prepared by the IUCN Species Survival Commission. IUCN, Gland, Switzerland, and Cambridge, United Kingdom.

Murphy, M. A. \& C. E. Jones. 1999. Observations on the genus Elymus (Poaceae: Triticeae) in Australia. Austral. Syst. Bot. 12: 593-604.

Rees, R. G. 1972. Agropyrum scabrum and its role in the epidemiology of Puccinia graminis in north-eastern Australia. Austral. J. Agric. Res. 23: 789-798.
Stanley, T. D. \& E. M. Ross. 1989. Flora of south-eastern Queensland, Vol. III. Queensland Dept. of Primary Industries Misc. Publ. QM88001.

Torabinejad, J. \& R. J. Mueller. 1993. Genome constitution of the Australian hexaploid grass Elymus scabrus (Poaceae: Triticeae). Genome 36: 147-151.

J. G. Carman \& C. F. Crane. 1987. Morphology and genome analysis of interspecific hybrids of Elymus scaber. Genome 29: 150-155.

Wang, S. 1999. Taxonomy of the Elymus scaber Complex (Triticeae: Poaceae). Ph.D. Thesis, University of Sydney, Sydney.

— \& M. J. Henwood. 1999. The taxonomic utility of micromorphological characters in Australian and New Zealand Elymus species (Poaceae). Telopea 8: $351-362$.

\& S. W. L. Jacobs. 2002. Elymus in Australia. Pp. 135-140 in P. Hernández, M. T. Moreno, J. I. Cubero \& A. Martin (editors), Proceedings of the 4th International Triticeae Symposium, 10-12 September 2001, Córdoba, Spain (Junta de Andalucia. Conserjeria de Agricultura y Pesca: Cordoba).

Wheeler, D. J. B., S. W. L. Jacobs \& R. D. B. Whalley. 2002. Grasses of New South Wales, 3rd ed. Botany Department, University of New England, Armidale, New South Wales, Australia. 


\section{$2 \mathrm{BHL}$ Biodiversity Heritage Library}

Jacobs, Surrey W L and Barkworth, Mary E. 2009. "A New Species of Elymus (Gramineae, Triticeae) from Eastern Australia." Novon a journal of botanical nomenclature from the Missouri Botanical Garden 19, 168-171.

View This Item Online: https://www.biodiversitylibrary.org/item/124658

Permalink: https://www.biodiversitylibrary.org/partpdf/121897

\section{Holding Institution}

Missouri Botanical Garden, Peter H. Raven Library

\section{Sponsored by}

Missouri Botanical Garden

\section{Copyright \& Reuse}

Copyright Status: Permission to digitize granted by rights holder Rights: https://www.biodiversitylibrary.org/permissions

This document was created from content at the Biodiversity Heritage Library, the world's largest open access digital library for biodiversity literature and archives. Visit BHL at https://www.biodiversitylibrary.org. 